\title{
KINERJA BADAN USAHA MILIK DESA DAN KONTRIBUSINYA BAGI PENDAPATAN ASLI DESA
}

\author{
Ni Kadek Sinarwati ${ }^{*}$, Made Aristia Prayudi ${ }^{1}$ \\ ${ }^{1}$ Universitas Pendidikan Ganesha, Indonesia \\ *e-mail: kadeksinar20@gmail.com
}

\begin{abstract}
Abstrak
Data Badan Pemberdayaan Masyarakat Provinsi Bali menunjukkan jumlah Badan Usaha Milik Desa (BUMDes) meningkat. Penelitian sebelumnya tentang kinerja BUMDes di Provinsi Bali terbatas pada kinerja Sumber Daya Manusia di BUMDes, namun penelitian tentang kinerja BUMDes sampai saat ini belum ditemukan. Penelitian ini bertujuan mendeskripsikan kinerja BUMDes di Provinsi Bali, kontribusi BUMDes bagi pendapatan asli desa (PADes), pendorong dan penghambat kinerja BUMDes, dan pendorong dan penghambat kontribusi BUMDes. Penelitian ini merupakan jenis penelitian deskriptif kuantitatif. Indikator kinerja terdiri dari kinerja keuangan kinerja non keuangan. Jenis data kualitatif yaitu tanggapan responden terhadap kuesioner yang kemudian dikuantitatifkan, hasil wawancara dan dokumen BUMDes. Populasi penelitian seluruh pelaksana operasional BUMDes di Provinsi Bali. Sampel ditentukan dengan metode Accidental sampling. Hasil penelitian menunjukkan BUMDes di Provinsi Bali memiliki kinerja keuangan dan non keuangan baik. Data menunjukkan 85,7 \% BUMDes mengalami peningkatan penjualan sebelum pandemi, meskipun tidak mengalami peningkatan penjualan selama pandemi, terdapat $21,4 \%$ BUMDes mengalami peningkatan modal. Sebagian besar (92,9\%) BUMDes mampu menyusun anggaran dan $64,3 \%$ mampu mengelola potensi desa. Pendorong kinerja BUMDes adalah pengelola dan partispasi masyarakat yang gigih dan kreatif. Penghambat kinerja adalah perbedaan pemahaman terhadap peraturan diantara para pengelola dan pembebanan pajak. Kontribusi BUMDes bagi Pendapatan Asi Desa meningkat dari tahun ke tahun. Pendorong kontibusi BUMDes adalah kesadaran dan kepatuhan terhadap peraturan pemerintah. Penghambat kontribusi adalah pandemi covid-19, dukungan pemerintah yang kurang optimal dan rendahnya kemampuan mengelola potensi desa.
\end{abstract}

Kata Kunci: BUMDes; Kinerja; Pendapatan Asli Desa

\begin{abstract}
Data from the Bali Province Community Empowerment Agency showed that the number of Village Owned Enterprises (BUMDes) increased. Previous research on the performance of BUMDes in Bali Province was limited to the performance of Human Resources in BUMDes, but research on the performance of BUMDes has not yet been found. This study aims to describe the performance of BUMDes in Bali Province, the contribution of BUMDes to original village revenue, the drivers and barriers to the performance of BUMDes, and the drivers and barriers to the contribution of BUMDes. This research was descriptive quantitative research. Performance indicators consist of financial and non-financial performance. The types of qualitative data were respondents' responses to questionnaires, interviews, and BUMDes documents. The research population was all BUMDes operational implementers in Bali Province. The sample was determined by the Accidental Sampling method. The results showed that BUMDes in Bali Province had excellent financial and non-financial performance. Data showed that $85.7 \%$ of BUMDes experienced an increase in sales before the pandemic. Although there was no increase in sales during the pandemic, $21.4 \%$ of BUMDes experienced a capital increase. The majority $(92.9 \%)$ of BUMDes could prepare a budget, and $64.3 \%$ managed village potential. The drivers of BUMDes performance were persistent and creative managers and community participation. Performance barriers were differences in understanding of the rules between managers and the imposition of taxes. The contribution of BUMDes to original village revenue has increased from year to year. The driving force for BUMDes' contribution is awareness and compliance with government regulations. The contribution barrier was the COVID-19 pandemic, suboptimal government support, and the low ability to manage village potential.
\end{abstract}

Key words: BUMDes; Performance; Original Village Revenue

This is an open access article under the CC BY-SA license.

Copyright @ 2021 by Author. Published by Universitas Pendidikan Ganesha.

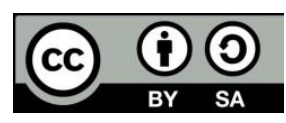




\section{PENDAHULUAN}

Upaya pengembangan BUMDes yang telah dilakukan oleh Kementerian Desa Pembangunan Daerah Tertinggal dan Transmigrasi diantaranya 1). Bantuan permodalan yang bertujuan untuk meningkatkan modal BUMDes serta perannya sebagai pendorong ekonomi desa dan membuat tenaga kerja baru di desa. Sejak tahun 2016 sampai dengan 2019 sudah disalurkan bantuan ke 4.231 BUMDes dengan total anggaran Rp. 211.500.000.000. 2). Pengembangan ekonomi lokal yang bertujuan meningkatkan jumlah dan kapasitas kelembagaan BUMDes dalam pengembangan ekonomi lokal. Sejak tahun 2018 sampai dengan 2019 telah dilakukan piloting ke 157 BUMDes, dengan bentuk kegiatan meliputi pembentukan kemitraan usaha, fasilitasi inkubasi bisnis (penguatan kapasitas sumber daya manusia dan kelembagaan). 3). Revitalisasi pasar desa yang bertujuan membantu merevitalisasi pasar desa sehingga dapat meningkatkan jumlah transaksi dan perputaran ekonomi di desa. Sejak tahun 2016 sampai dengan 2019 sudah dilakukan revitalisasi pasar desa sebanyak 94 pasar desa (Rahmawati, 2020).

Perhatian serius pemerintah terhadap pengembangan BUMDes dengan indikator penerbitan UndangUndang dan Peraturan Menteri Desa, pemberian bantuan modal dan program pendampingan, idealnya mampu meningkatkan kinerja BUMDes. Penelitian tentang kinerja BUMDes telah dilakukan oleh (Fay, 2017) menganalisis kinerja sosial dan finansial unit Usaha Simpan Pinjam BUMDes di Desa Ngaso Kabupaten Rukan Hulu. Berbeda dengan penelitian sebelumnya, dengan menggunakan lokasi di kabupaten yang sama, (Afrijal \& Ramadhani, 2016) membandingkan kinerja keuangan seluruh BUMDes yang terdapat di Kabupaten Rukan Hulu. (Qosjim, 2017) menganalisis tata kelola dan keberlanjutan BUMDEs di Kabupaten Lumajang menemukan bahwa faktor yang menentukan BUMDes berhasil adalah penatakelolaan kelembagaan. Analisis kinerja pengelola BUMDes di Desa Akedotilou dengan menggunakan lima indikator yaitu produktivitas, pelayanan, responsivitas, responsibilitas dan akuntabilitas pengelola BUMDes melakukan riset yang dilakukan (Caturharjo, 2018). Analisis kinerja organisasi BUMDes dengan menggunakan dua indikator kinerja organisasi yaitu kemampuan mengelola anggaran dengan sub indikator menyusun dan menyampaikan laporan keuangan. Indikator kinerja organisasi yang kedua adalah kemampuan mengelola potensi desa dilakukan oleh (Madjodjo \& Dahlan, 2020). Analisis kinerja BUMDes dalam mengelola asset desa di Desa Putat Lor menggunakan indikator kemampuan mengelola asset desa yang diukur dari kuantitas program yang terlaksana dan kualitas pelaksana program adalah riset dari (Musyafak, 2014). Kuantitas program dihitung dengan membandingkan program yang terlaksana dengan program yang ditetapkan. Kualitas pelaksana program diukur dengan menganalisis kesesuaian pekerjaan pelaksana program terhadap fungsi yang telah ditetapkan di awal.

BUMDes merupakan lembaga ekonomi dan sosial yang didirikan untuk meningkatkan Pendapatan Asli Desa (PADes). Sebagai lembaga ekonomi yang berada di desa, kehadiran BUMDes hendaknya tidak menjadi kompetitor terlebih lagi jangan sampai menjadi menjadi predator bagi usaha ekonomi masyarakat desa. BUMDes sebagai lembaga sosial maknanya kehadiran BUMDes diharapkan mampu menyelesaikan masalah sosial yang terjadi di desa. Penelitian tentang kontribusi BUMDes diantaranya, (Ni Kadek Sinarwati, 2019) menemukan bahwa kehadiran BUMDes mampu mengurangi pengangguran dan mencegah perpindahan penduduk dari desa ke kota. Penelitian kontribusi BUMDes bagi (PADes) diantaranya (Ni Kadek Sinarwati, 2019) menemukan 
bahwa BUMDes di Kabupaten Langkat belum berkontribusi signifikan bagi (PADes), hal ini dikuatkan dengan hasil amatan pada tahun 2016 BUMDes tidak melakukan penyetoran hasil usaha ke kantor desa. Penelitian (Jaryono \& Tohir, 2019) menemukan BUMDes Mitra Makmur Desa Susukan memberikan kontribusi bagi peningkatan pendapatan asli desa sebesar $\mathrm{Rp} 18.000 .000$ pada tahun 2017. Pendirian BUMDes bertujuan untuk melakukan kegiatan ekonomi, mengembangkan investasi, memenuhi kebutuhan umum masyakarakat desa, mengelola potensi desa dan meningkatkan pendapatan asli desa.

Salah satu upaya untuk mencapai tujuan pendirian BUMDes adalah dengan meningkatkan kinerja BUMDes. Kinerja merupakan sebuah konsep multidimensi dan hubungan antara kinerja dengan kewirausahaan tergantung dari indikator yang digunakan untuk mengukur kinerja (Lumpkin $n$ Dess). Pengukuran kinerja secara objektif mengacu pada indikator kuantitatif. Pengukuran subjektif tergantung pada pendapat subjektif dari tim ahli (Zehir Cemal, Can Esin, 2015). Indikator keuangan yang dapat digunakan untuk mengukur kinerja usaha adalah; peningkatan jumlah penjualan, peningkatan jumlah modal dan peningkatan jumlah tenaga kerja (Munizu, 2010). Kinerja suatu organisasi di sektor publik mampu dinilai berdasarkan kemampuan dalam mengelola anggaran, setiap anggaran yang dibuat (BUMDes) hendaknya dilaporkan melalui laporan keuangan yang telah ditentukan pada satu periode waktu tertentu (Madjodjo \& Dahlan, 2020). Study analisis kinerja pengelolaan asset BUMDes di Desa Putatlor Kabupaten Gresik menemukan bahwa kinerja BUMDes belum memberikan dampak secara maksimal pada pengembangan asset desa (Madjodjo \& Dahlan, 2020). BUMDes di Provinsi Bali mengalami peningkatan jumlah. Tabel 1 menyajikan jumlah data BUMDes di tiap kabupaten/kota di
Provinsi Bali sejak tahun 2016 sampai dengan tahun 2018.

Tabel 1. Jumlah Badan Usaha Milik Desa (BUMDes) Di Tiap

Kabupaten/Kota di Provinsi Bali, Tahun 2016-2018 (unit)

\begin{tabular}{llrrrc}
\hline No & $\begin{array}{l}\text { Kabupaten/ } \\
\text { Kota }\end{array}$ & Desa & 2016 & 2017 & 2018 \\
\hline 1 & Buleleng & 148 & 85 & 100 & 103 \\
\hline 2 & Jembrana & 51 & 40 & 40 & 41 \\
\hline 3 & Tabanan & 133 & 72 & 79 & 86 \\
\hline 4 & Badung & 62 & 13 & 34 & 40 \\
\hline 5 & Denpasar & 43 & 6 & 6 & 11 \\
\hline 6 & Gianyar & 70 & 14 & 21 & 41 \\
\hline 7 & Bangli & 72 & 29 & 39 & 39 \\
\hline 8 & Klungkung & 59 & 28 & 35 & 39 \\
\hline 9 & Karangasem & 78 & 63 & 64 & 68 \\
\hline & Jumlah & 716 & 350 & 418 & 468 \\
\hline
\end{tabular}

Sumber: Badan Pemberdayaan Masyarakat Desa Provinsi Bali, 2018

Tabel 1 menunjukkan terjadi peningkatan jumlah unit BUMDes sejak tahun 2016-2017. Persentase peningkatan BUMDes di Provinsi Bali dari tahun 2016 ke tahun 2017 sebesar 19 persen dan persentase peningkatan dari tahun 2017 ke tahun 2018 sebesar 12 persen, sehingga rata-rata persentase peningkatan selama tiga tahun terakhir adalah 15,5 persen. Jumlah unit BUMDes yang meningkat merupakan salah satu indikator tingginya animo masyarakat di Provinsi Bali membentuk usaha di desanya.

Peningkatan jumlah BUMDes di Provinsi Bali terjadi setelah tersedianya payung hukum yang jelas tentang pendirian dan tata cara pengelolaan BUMDes dan perhatian yang sangat serius dari Pemerintah Pusat terhadap perkembangan BUMDes. Kuantitas BUMDes yang meningkat idealnya diikuti oleh peningkatan kualitas. Salah satu indikator BUMDes berkualitas adalah BUMDes yang memiliki kinerja keuangan maupun kinerja non keuangan yang baik. Penelitian tentang kinerja BUMDes di Provinsi Bali belum ditemukan, sehingga memotivasi penelitian ini untuk meneliti kinerja BUMDes mengingat jumlah BUMDes di Provinsi Bali yang meningkat dan 
program pengembangan BUMDes dari Kementerian Desa sudah dilaksanakan. Penelitian ini bertujuan untuk mendeskripsikan kinerja BUMDes, kontribusi BUMDes terhadap pendapatan asli desa (PADes) di Provinsi Bali, pendorong dan penghambat kinerja BUMDes, dan pendorong dan penghambat kontribusi BUMDes terhadap pendapatan asli desa.

\section{METODE}

Penelitian ini merupakan jenis penelitian deskriptif kuantitatif yang mendeskripsikan data kinerja dan kontribusi BUMDes bagi peningkatan pendapatan asli desa di Provinsi Bali. Kinerja dalam penelitian ini dibedakan menjadi dua yaitu kinerja keuangan dengan indikator: peningkatan penjualan dan peningkatan modal mengacu riset (Munizu, 2010) dan kinerja non keuangan dengan indikator: kemampuan mengelola anggaran dan kemampuan mengelola potensi desa mengacu riset (Madjodjo \& Dahlan, 2020).

Jenis data adalah data kuantitatif yaitu yaitu tanggapan responden terhadap kuesioner yang dikuantitatifkan, hasil wawancara dan data dokumen BUMDes. Berdasarkan sumbernya jenis data merupakan data primer, karena data dikumpulkan untuk pertama kalinya oleh peneliti. Populasi adalah seluruh pelaksana operasional BUMDes di Provinsi Bali. Sampel ditentukan dengan metode Sampling Aksidental yaitu teknik penentuan sampel berdasarkan kebetulan, yaitu siapa saja yang secara kebetulan bertemu dengan peneliti dapat digunakan sebagai sampel, bila dipandang orang yang kebetulan ditemui itu layak sebagai sumber data (Sugiyono, 2010). Kriteria yang digunakan untuk menentukan kelayakan sebagai sumber data adalah sampel merupakan pelaksana operasional khususnya ketua BUMDes di Provinsi Bali sejumlah 140 orang. Analisis data dilakukan dengan menghitung hasil angket, menganalisis, menyajikan dan menelaah data, dan diakhiri dengan menyimpulkan.

\section{HASIL DAN PEMBAHASAN}

Karakteristik responden ditinjau dari tingkat pendidikan terakhir mayoritas $(57,1)$ persen ketua pelaksana operasional BUMDes berpendidikan SMA; 21,4 persen berpendidikan sarjana $S 1$ dan 14,3 persen berpendidikan sarjana S2. Karakteristik responden ditinjau dari jenis kelamin 92,9 persen reponden berjenis kelamin laki-laki dan 7,1 persen berjenis kelamin perempuan. Responden yang menyatakan pernah mengikuti kegiatan pelatihan/pendampingan sebanyak 57,1 persen dan 42,9 persen menyatakan tidak pernah mengikuti pelatihan. Data karakteristik responden ditinjau dari lama waktu menjadi ketua pelaksana operasional BUMDes menunjukkan mayoritas $(71,4)$ persen dengan jangka waktu lebih dari tiga tahun, sebanyak 21,4 persen dengan jangka waktu satu sampai dua tahun dan sebesar 7,2 persen menyatakan bahwa mereka menjadi ketua pelaksana operasional BUMDes dengan jangka waktu di atas dua sampai dengan tiga tahun. Karakteristik responden ditinjau dari segi umur menunjukkan data bahwa usia termuda adalah 32 tahun dan usia tertinggi responden adalah 60 tahun, sehingga rata-rata umur ketua BUMDes adalah 45 tahun dan ini tergolong usia produktif.

Data ketua pelaksana operasional BUMDes di Provinsi Bali mayoritas berpendidikan SMA, berjenis kelamin laki-laki, sudah pernah mengikuti kegiatan pelatihan, sudah menjadi ketua pelaksana operasional dengan waktu lebih dari tiga tahun, dengan rata-rata usia 45 tahun. Kondisi ini bermakna bahwa BUMDes memiliki sumber daya manusia yang berpotensi untuk dikembangkan untuk mengelola BUMDes menggali dan mengembangkan potensi desa, dalam rangka membangun usaha bisnis di desa yang mampu meningkatkan 
pendapatan asli desa menuju kemandirian desa. Jumlah modal usaha BUMDes terendah adalah $\mathrm{Rp}$ 31.309.500 dan jumlah modal tertinggi adalah Rp. 3.588. 600.892. Sebagian besar BUMDes $(71,4)$ persen memiliki unit usaha simpan pinjam, 14, 2 persen memiliki usaha bisnis sosial, dan 14,4 persen melakukan usaha perdagangan.

\section{Kinerja BUMDes}

Kinerja merupakan hasil dari usaha yang yang umumnya diukur dengan indikator keuangan dan non keuangan. Indikator keuangan yang dapat digunakan untuk mengukur kinerja seperti peningkatan penjualan, peningkatan modal, peningkatan keuntungan, peningkatan asset dan ukuran perusahaan (Munizu, 2010); (Gaganis et al., 2019); (Felício et al., 2014), dan indikator non keuangan seperti kemampuan mengelola anggaran, kualitas pelayanan, kepuasan konsumen, peningkatan luas pasar, kegiatan pertanggungjawaban sosial perusahaan/CSR (Ittner \& Larcker, 2003); (Madjodjo \& Dahlan, 2020); (Basri, 2015); (Okwoma, 2012). Data kinerja BUMDes pada penelitian ini diukur dengan peningkatan penjualan dan peningkatan modal. Data peningkatan penjualan dan modal BUMDes sebelum dan selama pandemi. Data peningkatan penjualan sebelum pandemi covid-19 merupakan tanggapan atas pernyataan "BUMDes yang saya kelola mengalami peningkatan penjualan sebelum pandemi covid-19", disajikan pada Gambar 1.

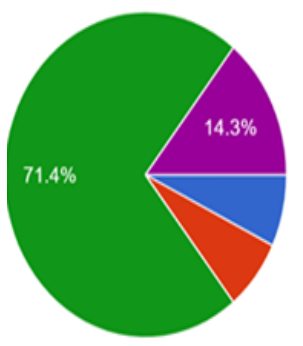

- Sangat Tidak Setuju - Tidak Setuju Cukup setuju - Setuju

- Sangat Setuju

Gambar 1. Peningkatan penjualan BUMDes sebelum pandemi covid-19
Gambar 1 menunjukkan bahwa mayoritas atau 85,7 persen $(71,4+14,3)$ responden menyatakan mengalami peningkatan penjualan sebelum terjadinya pandemi covid-19. Sedangkan sebagian kecil (14,3 persen) yang menyatakan tidak mengalami peningkatan penjualan. Jenis usaha BUMDes yang menjadi responden penelitian ini adalah bisnis sosial, jasa keuangan, perantara dan perdagangan. Bisnis sosial yang dijalankan BUMDes adalah mengelola hutan desa, seperti yang dilakukan BUMDes Karya Sejahtera di Desa Sepang Kecamatan Busung Biu Kabupaten Buleleng.

Selama terjadi pandemi covid19 semua BUMDes tidak mengalami peningkatan penjualan, namun demikian terdapat BUMDes yang mengalami peningkatan modal, meskipun jumlahnya tidak mayoritas. Tanggapan responden atas pernyataan "BUMDes yang saya kelola mengalami peningkatan modal selama pandemi covid-19" disajikan disajikan pada Gambar 2.
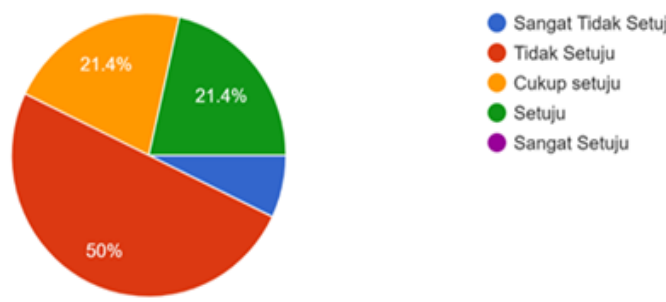

Gambar 2. Peningkatan modal BUMDes selama pandemi covid-19

Gambar 2 menunjukkan bahwa selama pandemi covid-19, terdapat 21,4 persen yang mengalami peningkatan modal meskipun terdapat 50 persen BUMDes yang menyatakan tidak mengalami peningkatan modal selama pandemi covid-19. BUMDes merupakan lembaga usaha yang didirikan oleh masyarakat dan pemerintah desa guna meningkatkan perekonomian desa. Dukungan dari pemerintah desa terhadap keberadaan BUMDes melalui penyertaan modal membuat BUMDes mampu bertahan ditengah pandemi, 
bahkan beberapa diantaranya mengalami peningkatan jumlah modal ditengah pandemi. Peningkatan jumlah modal yang dialami BUMDes mengindikasikan bahwa BUMDes mampu bertahan memberikan pelayanan kepada masyarakat desa meskipun ditengah pandemi. Jasa pelayanan yang diberikan oleh BUMDes kepada masyarakat diantaranya pelayanan pembayaran listrik, air dan jasa transfer. Terdapat BUMDes yang melakukan kerjasama dengan bank umum, diantaranya BUMDes Arta Dharma Duta di Desa Menanga, Kecamatan Rendang Kabupaten Karangasem bekerjasama dengan Bank BRI melalui program Desa Brilian. BUMDes Dana Merta Desa Tangkup Kecamatan Sidemen memiliki bidang usaha PPOB (Payment Point Online Bank) yang merupakan kerjasama sebagai agen dari PT. Arindo Nusantara. BUMDes tidak mengalami peningkatan penjualan (penjualan tetap) tetapi mengalami peningkatan modal selama pandemi bermakna bahwa usaha BUMDes mampu bertahan karena jenis usaha yang dilakukan untuk memenuhi kebutuhan pokok masyarakat desa. Kemampuan BUMDes di Provinsi Bali yang menjadi sampel penelitian ini diantaranya disebabkan oleh digitalisasi dan pengolahan potensi desa. Hasil ini sejalan dengan temuan riset (Pratiwi \& Novianty, 2020) yang menemukan bahwa BUMDes Karya Mandiri di Desa Cibodas Bandung Barat, mampu bertahan di tengah pandemi COVID-19 melalui kearifan lokal dan digitalisasi usaha. Digitalisasi usaha BUMDes diantaranya usaha pembayaran PBB, Pembayaran kredit multifinance dan penerimaan pembayaran lisrik, air dan iuran BPJS dilakukan secara online. Usaha BUMDes dalam mengelola potensi desa, dapat ditemukan pada unit usaha pengelolaan hutan desa yang dilakukan BUMDes Karya Sejahtera di Desa Sepang Kabupaten Buleleng. Peningkatan jumlah penjualan dan modal BUMDes menjadi suatu bukti bahwa kinerja keuangan BUMDes yang baik.

Data kinerja BUMDes, selain diukur dengan kinerja keuangan yaitu peningkatan penjualan dan modal, penelitian ini juga mengukur kinerja dengan menggunakan indikator non keuangan yaitu kemampuan mengelola anggaran dan kemampuan mengelola potensi desa. Kemampuan mengelola anggaran menggunakan item pernyataan penyusunan laporan keuangan dan penyampaian laporan keuangan kepada forum Musdes. Data penyusunan laporan keuangan yang merupakan tanggapan atas pernyataan "Sebagai pelaksana operasional kami selalu menyusun laporan keuangan tahunan atas seluruh unit usaha BUMDes" disajikan pada Gambar 3.

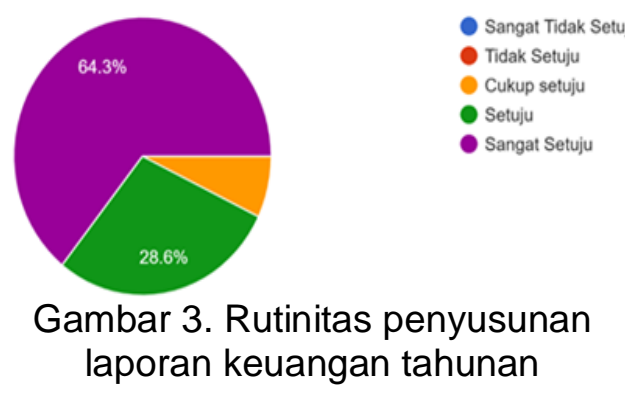

Gambar 3 menunjukkan bahwa pelaksana operasional BUMDes mampu dan selalu/rutin menyusun laporan keuangan atas seluruh unit usaha yang dimiliki. Terdapat 92,9 persen $(64,3+28,6)$ BUMDes yang sudah rutin menyusun laporan keuangan tahunan, hanya 7,1 persen BUMDes yang belum rutin menyusun laporan keuangan tahunan. Modal utama BUMDes berasal dari penyertaan dari pemerintah desa yang berasal dana pengalokasian dana desa. Beberapa BUMDes di Provinsi Bali yang menjadi responden penelitian ini, selain mengelola dana dari penyertaan pemerintah desa, juga memperoleh modal dari Pemerintah Provinsi Bali melalui program Gerbang Sadu Mandara. Modal yang dikelola BUMDes yang berasal dari Pemerintah baik pusat maupun daerah, mewajibkan BUMDes melaporkan pengelolaan 
dana melalui media laporan keuangan. Mayoritas ketua pelaksana operasional BUMDes yang sudah menyusun laporan keuangan menunjukkan bahwa BUMDes sudah berupaya mewujudkan konsep akuntabilitas. Akuntabilitas merupakan salah satu syarat untuk mewujudkan tata kelola yang baik (Partisipasi et al., 2017). Akuntabilitas dimaknai sebagai keterkaitan antara pemegang kendali yang mengelola entitas dengan bagian yang mempunyai kekuatan formal terhadap pihak pengendali tersebut (Sadjiarto, 2000). Implementasi konsep akuntabilitas penelitian yang dilakukan oleh BUMDes dilihat adanya hubungan antara pelaksana operasional sebagai pengelola entitas BUMDes dengan pihak yang memiliki kekuatan formal dalam hal ini pemerintah desa sebagai penasehat BUMDes. Hubungan diwujudkan dengan penyusunan laporan pertanggungjawaban penggunaan dana melalui media laporan keuangan. Pelaksana operasional yang sudah menyusun laporan keuangan menunjukkan bahwa telah terjadi tata kelola BUMDes yang baik.

Indikator kinerja non keuangan BUMDes ditinjau dari kemampuan mengelola potensi desa, yang merupakan tanggapan ketua pelaksana operasional BUMDes atas pernyataan “ bersama dengan penasehat dan pengawas kami selalu menyampaikan laporan keuangan kepada forum Musdes" disajikan pada Gambar 4.

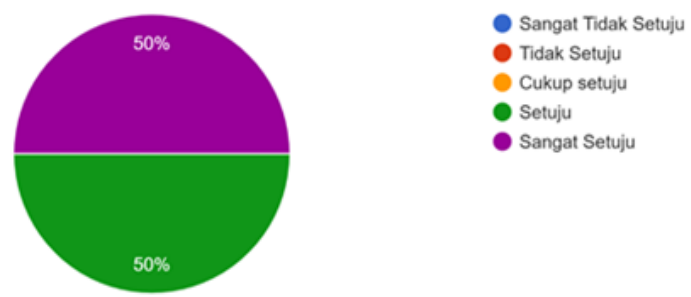

Gambar 4. Penyampaian laporan keuangan tahunan BUMDes

Gambar 4 menunjukkan bahwa seluruh BUMDes menyampaikan laporan keuangan tahun pada forum
Musyawarah desa (Musdes). Laporan keuangan tahunan, merupakan media pertanggungjawaban pengelolaan dana BUMDes kepada masyarakat melalui Musdes. Hasil wawancara dengan ketua BUMDes menyatakan selain menyampaikan laporan keuangan di Forum BUMDes, laporan keuangan juga disampaikan ke Badan Pemberdayaan Masyarakat Desa (BPMD) baik ditingkat Kabupaten/Kota maupun ditingkat Provinsi. Musyawarah desa merupakan musyawarah antara Badan Permusyawaratan Desa, Pemerintah desa dan unsur masyarakat yang diselenggarakan oleh badan permusyawaratan desa untuk menyepakati hal yang bersifat strategis (Indonesia, 2021).

Kedudukan Musdes di BUMDes adalah sebagai salah satu bagian dari perangkat organisasi bersama-sama dengan penasehat, pelaksana operasional dan pengawas. Musdes merupakan pemegang kekuasaan tertingi pada BUMDes yang memiliki kewenangan menetapkan pendirian BUMDes, menetapkan anggaran, mengangkat dan memberhentikan pelaksana operasional, mengangkat pengawas, memberikan persetujuan penyertaan modal dan tugas strategis lainnya. Penyampaian laporan keuangan BUMDes pada forum Musdes dan kepada BPMD merupakan bentuk telah diterapkannya konsep transparansi di BUMDes. Tranparansi merupakan pengungkapan semua informasi mencakup hokum, kebijakan dan kelembagaan yang menghasilkan informasi dan saluran distribusi dengan penekanan pada aksessibilitas, grekuensi dan keandalan informasi (Baraibar-Diez \& Sotorrío, 2018). Transparansi merupakan nilai kunci bagi pemerintah yang dapat dipercaya

Penyusunan laporan keuangan dan penyampaiannya secara berkala pada forum BUMDes dan BPMD merupakan suatu aktivitas yang mendukung stewardship theory. Teori menyatakan bahwa manajemen memiliki keinginan untuk melakukan aktivitas yang baik dan memberikan 
pelayanan terbaik dalam pengelolaan assets suatu perusahaan. (Donaldson \& Davis, 1991). Pelaksana operasional sebagai manajemen BUMDes melakukan upaya terbaik dalam menjalankan perannya dan mempertanggungjawabkan

kegiatannya sebagai pelayan masyarakat kepada pemilik dana dalam hal ini masyarakat yang diwakili oleh forum Musdes. Hasil riset ini menemukan bahwa BUMDes menyampaikan laporan pertanggungjawaban pengelolaan dana, menerapkan konsep transparansi sejalan dengan temuan penelitian (Irawati \& Martanti, 2017) yang menemukan bahwa telah terjadi praktek akuntansi yang transparan dan penyusunan laporan keuangan dalam pengelolaan asset desa yang dilakukan BUMDes di Desa Karangbendo Kecamatan Ponggok Kabupaten Blitar. Terimplementasinya konsep Akuntabilitas dan Transparansi pada pengelolaan BUMDes merupakan indikator dari kinerja BUMDes yang baik.

Data potensi desa dan kemampuan mengelola potensi desa disajikan pada Gambar 5 dan Gambar 6. Data potensi desa, merupakan tanggapan responden atas pernyataan" desa saya memiliki beberapa potensi" Data keberadaan potensi desa disajikan pada Gambar 5.

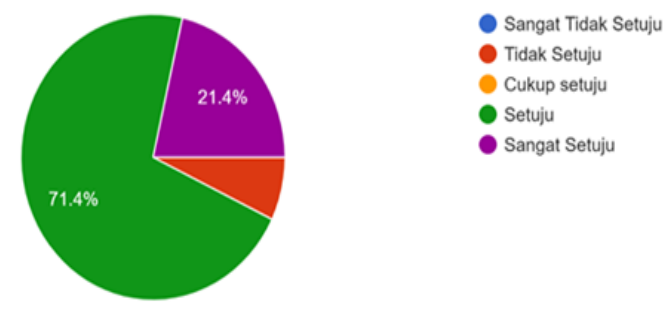

Gambar 5. Keberadaan potensi desa

Gambar 5 menunjukkan bahwa 92, 8 $(71,4+21,4)$ persen responden menyatakan bahwa desanya memiliki potensi, hanya 7,2 persen responden yang menyatakan bahwa desa mereka tidak memiliki potensi. Data kemampuan pelaksana operasional mengelola potensi desa yang merupakan tanggapan atas penyataan "kami mampu mengelola potensi desa demi kemajuan BUMDes", disajikan pada Gambar 6.
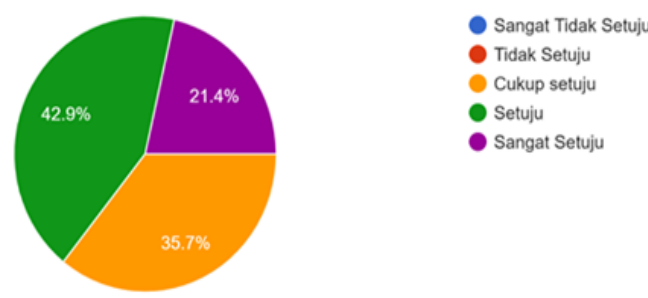

Gambar 6. Kemampuan mengelola potensi desa

Gambar 6 menunjukkan bahwa 64,3 $(42,9+21,4) \quad$ persen responden menyatakan mampu mengelola potensi desa dan terdapat 35,7 persen responden yang tidak mampu mengelola potensi desa. Petikan wawancara dengan Bapak I Made Rincim Astawa sebagai ketua BUMDes Karya Sejahtera di Desa Sepang Kecamatan Busung Biu Kabupaten Buleleng yang dilakukan pada bulan Juli 2021 disajikan berikut ini

"BUMDes Karya Sejahtera menjalankan usaha bisnis sosial dalam bentuk pengelolaan potensi desa yaitu hutan desa. Sebelum kehadiran BUMDes, terjadi pembabatan hutan yang dijadikan lahan perkebunan, hutan diubah fungsinya dan dilakukan secara illegal. Kehadiran BUMDes yang mengelola hutan desa dengan ditanami pohon durian, alpokat, kemiri dan pohon lainnya yang secara ekonomi menghasilkan".

Kehadiran BUMDes yang telah mampu mengelola potensi desa dalam hal ini hutan desa, tidak hanya mampu memberikan profit berupa hasil penjualan tanaman yang memiliki nilai ekonomi, kehadiran BUMDes juga memberikan benefit atau manfaat sosial yaitu penurunan pembabatan hutan yang dilakukan secara illegal. Profit dan benefit yang diterima masyarakat atas hadirnya BUMDes dalam mengelola potensi desa menunjukkan bahwa BUMDes berkinerja baik. 


\section{Kontribusi BUMDes bagi pendapatan asli desa}

Pengukuran kontribusi BUMDes

terhadap pendapatan asli desa, menggunakan pernyataan untuk mengetahui persentase alokasi keuntungan yang dialokasikan kepada pendapatan asli desa. Alokasi keuntungan unit usaha BUMDes untuk PADes meningkat dari tahun ketahun, hal ini disajikan pada Gambar 7.

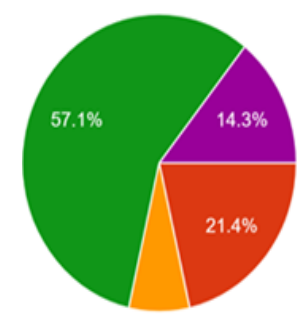

$$
\begin{aligned}
& \text { Sangat Tidak Setuju } \\
& \text { Tidak Setuju } \\
& \text { Cukup setuju } \\
& \text { Setuju } \\
& \text { Sangat Setuju }
\end{aligned}
$$

Gambar 7. Alokasi keuntungan BUMDes untuk PADes meningkat setiap tahun

Gambar 7 menunjukkan bahwa 61,4 $(57,1+14,3) \quad$ persen responden menyatakan bahwa alokasi keuntungan BUMDes untuk PADes meningkat setiap tahun, hanya 21,4 persen responden yang menyatakan bahwa alokasi keuntungan untuk PADes tidak meningkat setiap tahunnya. Persentase alokasi keuntungan BUMDes untuk PADes berada dalam rentang kurang dari 5 persen, diantara 5 sampai 10 persen, di atas 10 sampai 15 persen dan di atas 15 persen. Data ini disajikan pada Gambar 8.
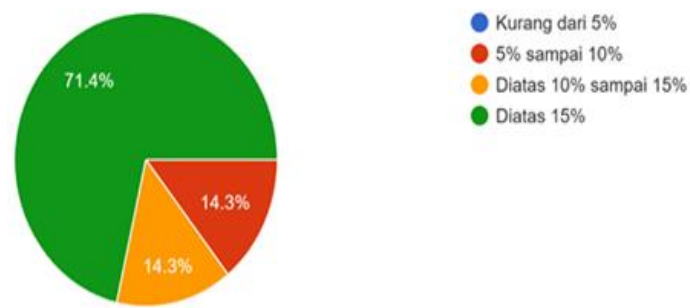

Gambar 8. Persentase alokasi keuntungan BUMDes untuk PADes

Gambar 8 menunjukkan terdapat 71,4 persen BUMDes mengalokasikan keuntungan untuk PADes di atas 15 persen. Persentase BUMDes yang mengalokasikan keuntungan dalam rentang 10 sampai 15 persen sebesar 14,3 persen dan terdapat 14,3 persen BUMDes yang mengalokasikan keuntungan dalam rentang 5 sampai 10 persen.

Petikan hasil wawancara dengan Bapak I Wayan Ridana ketua BUMDes Arta Dharma Duta di Desa Menanga Kecamatan Rendang Kabupaten Karangasem pada bulan Juli 2021 disajikan berikut ini

"Alokasi keuntungan BUMDes yang disetorkan ke Desa untuk menambah pendapatan asli desa tahun 2020 sebesar Rp 30.000.000 atau sekitar 20 persen dari total keuntungan BUMDes, tahun ini direncanakan menyetorkan keuntungan sebesar 60 persen".

Unit usaha yang dijalankan BUMDes Arta Dharma Duta adalah PAM desa, peternakan, perdagangan dan bekerjasama dengan bank BRI melalui program desa Brilian memberikan jasa simpan-pinjam dan transfer. BUMDes ini mengelola potensi desa berupa sumber air dan dijadikan usaha penyediaan air desa minum (PAM) desa, mengelola potensi peternakan ayam dan dikelola menjadi perdagangan telor dan pakan ayam.

Motivasi ketua BUMDes yang tinggi dalam mengembangkan usaha terdorong oleh harapan untuk mencapai tujuan meningkatkan ekonomi desa dalam rangka mewujudkan desa mandiri dan masyarakat yang sejahtera. Perilaku ketua BUMDes yang memiliki motivasi tinggi sesuai dengan teori ekspektasi yang dikemukakan Victor vroom dalam (Parijat, 2014). Teori ini menyatakan karyawan memiliki tujuan pribadi yang mereka ingin capai dan menjadi alasan mereka bekerja pada suatu perusahaan. Tujuan pribadi ini dapat dipenuhi melalui reward dari perusahaan. Motivasi kerja yang tinggi ketua BUMDes mengembangkan BUMDesnya, jika dihubungkan dengan toeri hirarki kebutuhan Maslow, motivasi kerja yang tinggi tersebut untuk memenuhi kebutuhan penghargaan dan aktualisasi diri. 


\section{Pendorong dan Penghambat Kinerja BUMDes}

Kinerja BUMDes yang baik dengan indikator peningkatan penjualan, peningkatan modal, kemampuan mengelola anggaran dan potensi desa, merupakan harapan semua pihak. BUMDes yang berkinerja baik tentu akan mampu mencapai tujuan pendirian BUMDes. Pencapaian kinerja BUMDes yang baik didorong oleh kondisi internal maupun eksternal BUMDes. Petikan wawancara dengan Bapak I Nyoman Ariana Ketua BUMDes Kutuh di Desa Kutuh Kecamatan Kuta Selatan Kabupaten Badung pada bulan Januari tahun 2019 berkenaan dengan hal-hal yang menjadi pendorong dan penghambat peningkatan penjualan BUMDes disajikan berikut ini.

"Selama ini peningkatan penjualan dan peningkatan modal yang terjadi di BUMDes disebabkan oleh pengelola BUMDes yang gigih dan kreatif dan dukungan atau partisipasi dari masyarakat. Faktor penghambat yang menjadi kendala yang dihadapi selama ini dalam pengelolaan BUMDes adalah pemahaman dan penafsiran terhadap Undang-Undang khususnya tentang BUMDes yang masih berbeda antara BUMDEs satu dengan yang lainnya dan penetapan pajak pada usaha BUMDes merupakan beban bagi pengelola".

Kesuksesan BUMDes

memerlukan pengelola yang berorientasi wirausaha yang tinggi. Orientasi wirausaha/entrepreneurship merupakan sikap inovatif, kreatif, dan berani menanggung risiko usaha. Orientasi kewirausahaan memiliki kontribusi yang signifikan terhadap kesuksesan perusahaan (Rosli Mahmood et al., 2013); (Frank et al., 2010); (Sok Phyra, Aron O'Cass, 2013). Hasil wawancara dengan Bapak I Wayan Sudarma ketua BUMDes Jagadhita, Desa Bebandem Kecamatan Bebandem Kabupaten Karangasem menyatakan bahwa pendorong pencapaian kinerja BUMDes adalah faktor internal dan eksternal, sedangkan faktor penghambat adalah dari pihak pemakai manfaat BUMDes khususnya peminjam dana BUMDes yang masih rendah kesadarannya untuk mengembalikan pinjaman tepat pada waktunya.

\section{Pendorong dan Penghambat Kontribusi BUMDes Untuk PADes}

Desa merupakan kesatuan pemerintahan terkecil pada tata pemerintahan di negara Indonesia. Keberadaan desa mendahului dari keberadaan negara di Indonesia. Desa telah ada sebelum negara Indonesia lahir. Desa adalah desa dan desa adat atau yang disebut dengan nama lain, selanjutnya disebut Desa, adalah kesatuan masyarakat hukum yang memiliki batas wilayah yang berwenang untuk mengatur dan mengurus urusan pemerintahan, kepentingan masyarakat setempat berdasarkan prakarsa masyarakat, hak asal usul, dan/atau hak tradisional yang diakui dan dihormati dalam sistem pemerintahan Negara Kesatuan Republik Indonesia (Undang-Undang Republik Indonesia No. 6 Tahun 2014 Tentang Desa, 2014). Bab Delapan UU Desa di Pasal 72 menyatakan bahwa pendapatan asli desa berasal dari hasil asset, hasil usaha, partisipasi dan swadaya, gotong-royong dan lain-lain pendapatan asli desa yang sah. Keuntungan dari unit usaha BUMDes merupakan salah satu sumber pendapatan asli desa mengingat BUMDes merupakan badan hukum yang dimiliki oleh desa dan mendapatkan modal dari penyertaan desa.

Keberadaan BUMDes Pasca diterbitkannya Peraturan Menteri Desa Nomor 11 Tahun 2021 bukan lagi sebagai badan usaha, akan tetapi sebagai sebuah badan hukum yang memiliki kekuatan hukum setelah memperoleh sertifikat badan hukum yang akan dikeluarkan oleh Kementerian Hukum dan HAM. BUMDes mengalami penguatan kelembagaan sehingga memiliki ruang gerak yang lebih luas untuk mengembangkan usaha. Peluang 
usaha yang lebih luas bagi BUMDes tentu akan berkorelasi dengan peningkatan penjualan, peningkatan modal. Kekuatan badan hukum yang dimiliki BUMDes memberi peluang BUMDes menerima penyertaan modal dari pihak swasta, masyarakat maupun dari sumber lainnya. Peningkatan jumlah modal yang dikelola menuntut kemampuan menyusun anggaran agar mampu mengelola dan mempertanggungjawabkan

pengelolaan modal kepada pemilik modal. Kecukupan modal yang tersedia jika dikelola dengan tetap akan meningkatkan kinerja BUMDes sehingga mampu meningkatkan kontribusi BUMDes bagi pendapatan asli desa.

Penguatan kelembagaan

BUMDes pasca Peraturan Pemerintah Nomor 11 Tahun 2021 secara umum merupakan faktor pendorong peningkatan penjualan dan modal, sehingga meningkatkan keuntungan dan berujung pada peningkatan kontribusi BUMDes bagi PADes. Data penelitian menunjukkan 71,4 persen BUMDes mengalokasikan keuntungan di atas 15 persen. BUMDes Arta Dharma Duta di Desa Menanga bahkan merencanakan meningkatkan alokasi keuntungan untuk PADes sebesar 20 persen pada tahun 2020 meningkat menjadi 60 persen pada akhir tahun 2021. Petikan hasil wawancara dengan Bapak I Wayan Ridana, ketua BUMDes Arta Dharma Duta di Desa Menanga pada bulan Juli 2021 tentang hal yang mendorong dan menjadi kendala peningkatan kontribusi BUMDes bagi PADes dan disajikan berikut ini

"BUMDes yang saya kelola memiliki rencana meningkatkan persentase pembagian keuntungan BUMDes yang disetorkan ke Desa untuk menambah pendapatan asli desa. Rencana itu didasari oleh Peraturan Pemerintah Nomor 11 Tahun 2021 pasal 40 yang menyebutkan bahwa modal BUMDes berasal dari: penyertaan modal desa, penyertaan modal masyarakat dan bagian dari laba usaha, dan pasal 60 yang menyatakan pembagian hasil usaha BUMDes yang diserahkan kepada Desa menjadi pendapatan asli Desa. Kendala dalam meningkatkan kontribusi BUMDes bagi PADes adalah faktor eksternal pandemi covid-19 yang menurunkan pendapatan masyarakat sehingga menurunkan pendapatan BUMDes. Kendala lainnya adalah dukungan pemerintah yang belum optimal."

Modal yang dikelola BUMDes Arta Dharma Duta berasal dari penyertaan modal desa, sehingga pengelola merencanakan mengalokasikan keuntungan keuntungan BUMDes 60 persen dikembalikan ke Desa untuk menambah PADes, sedangkan 40 persen akan digunakan untuk menambah laba usaha tahun sebelumnya atau secara akuntansi akan menjadi tambahan modal dengan nama akun laba ditahan. Kondisi ini menunjukkan kepatuhan pengelola kepada peraturan perundang-undangan yang mengatur tata kelola BUMDes. Kesadaran dan kepatuhan terhadap peraturan menjadi salah satu pendorong peningkatan kontribusi BUMDes bagi PADes. BUMDes Desa Menanga mengharapkan perhatian pemerintah yang lebih optimal dalam memberikan pelatihan dan pendampingan mengelola BUMDes dan mengelola potensi desa untuk pengembangan usaha BUMDes.

\section{SIMPULAN DAN SARAN}

Hasil Penelitian menunjukkan bahwa dengan menggunakan indikator keuangan yaitu peningkatan penjualan dan peningkatan modal, kinerja BUMDes di Provinsi Bali dapat dinyatakan baik, terdapat 85,7 persen BUMDes mengalami peningkatan penjualan sebelum pandemi covid-19. Kinerja selama pandemi ditinjau dari penjualan tidak mengalami peningkatan, tetapi 21,4 persen BUMDes mengalami peningkatan modal selama pandemi. Indikator kinerja non keuangan yaitu kemampuan mengelola anggaran dan kemampuan mengelola potensi desa dapat dinyatakan baik. Kemampuan BUMDes mengelola anggaran dinilai 
dari kemampuannya menyusun laporan keuangan tahunan dan menyampaikan laporan tersebut pada forum musdes. Terdapat 92,9 persen BUMDes yang menyusun laporan keuangan tahunan secara berkala dan menyampaikan laporan itu ke forum musdes dan ke Badan Pemberdayaan Masyarakat Desa. Kinerja BUMDes dinilai dari kemampuan mengelola potensi desa menunjukkan hasil yang baik, terdapat 64,3 persen BUMDes yang mampu mengelola potensi desa.

Kontribusi BUMDes untuk PADes dari tahun ketahun semakin meningkat. Alokasi keuntungan BUMDes kepada PADEs terendah adalah 5 persen dan terdapat 71,4 persen BUMDes yang mengalokasikan keuntungan di atas 20 persen. Faktor pendorong peningkatan kinerja BUMDes adalah pengelola BUMDes yang gigih dan kreatif serta partisipasi masyarakat desa. Faktor penghambat kinerja BUMDes adalah pemahaman terhadap peraturan terkait BUMDes yang berbeda diantara para pengelola dan ketentuan pajak bagi BUMDes yang dianggap membebani BUMDes. Faktor pendorong peningkatan kontribusi bagi PADes adalah kesadaran dari pengelola BUMDes yang dituangkan pada Anggran Dasar untuk semakin meningkatkan kontribusi dan kepatuhan pada peraturan pemerintah. Penghambat kontribusi adalah dukungan pemerintah yang belum optimal dan rendahnya kemampuan mengelola potensi desa.

Temuan khususnya 35,7 persen pengelola BUMDes menyatakan tidak mampu mengelola potensi desa, sementara 92, 8 persen menyatakan bahwa desa mereka memiliki potensi. Karakteristik responden tentang keikutsertaan pada kegiatan pelatihan menunjukkan bahwa terdapat 42,9 responden belum pernah mengikuti kegiatan pelatihan, maka disarankan kepada pemerintah khususnya Badan Pemberdayaan Masyarakat Desa yang menaungi BUMDes untuk memberikan pelatihan khususnya tentang cara mengelola potensi desa. Kepada
Perguruan Tinggi disarankan melakukan kegiatan pengabdian masyarakat dan mengimplementasikan MBKM (Merdeka Belajar Kampus Merdeka) dengan melibatkan BUMDes. Kepada peneliti berikutnya disarankan untuk menguji faktor-faktor yang mempengaruhi kinerja BUMDes.

\section{DAFTAR PUSTAKA}

Afrijal, \& Ramadhani. (2016). Analisis Perbandingan Kinerja Keuangan Badan Usaha Milik Desa (BUMDES) di Kabupaten Rokan Hulu. Jurnal Ilmiah Cano Ekonomos, 5(1), 1-10.

Baraibar-Diez, E., \& Sotorrío, L. L. (2018). O efeito mediador da transparência na relação entre responsabilidade social corporativa e reputação corporative. Revista Brasileira de Gestao de Negocios, 20(1), 5-21. https://doi.org/10.7819/rbgn.v20i1. 3600

Basri, Y. M. (2015). Pengukuran Kinerja Non Finansial Dalam Meningkatkan Kinerja Finansial: Study Literatur. PhD Proposal, 1(2), 114-126.

Caturharjo, D. (2018). Analisis Kinerja Pengelola Badan Usaha Milik Desa Catur Mandiri Desa Caturharjo.

Donaldson, L., \& Davis, J. H. (1991). Stewardship Theory or Agency Theory: CEO Governance and Shareholder Returns. Australian Journal of Management, 16(1), 49-64.

https://doi.org/10.1177/031289629 101600103

Fay, D. L. (2017). Analisis Kinerja Sosial dan Kinerja Keuangan Lembaga Keuangan Mikro (LKM) Usaha Ekonomi Desa-Simpan Pinjam (UED-SP) Badan Usaha Milik Desa (BUMDes) Ngaso Mandiri Desa Ngaso Kecamatan Ujung Batu Kabupaten Rokan Hulu. Angewandte Chemie International Edition, 6(11), 951952. 
Felício, J. A., Couto, E., \& Caiado, J. (2014). Human capital, social capital and organizational performance. Management Decision, 52(2), 350-364. https://doi.org/10.1108/MD-042013-0260

Frank, H., Kessler, A., \& Fink, M. (2010). Entrepreneurial Orientation and Business Performance - A Replication Study. Schmalenbach Business Review, 62(2), 175-198. https://doi.org/10.1007/bf0339680 4

Gaganis, C., Pasiouras, F., \& Voulgari, F. (2019). Culture, business environment and SMEs' profitability: Evidence from European Countries. Economic Modelling, 78, 275-292. https://doi.org/10.1016/j.econmod. 2018.09.023

Irawati, D., \& Martanti, D. E. (2017). Transparasi Pengelolaan Laporan Keuangan BUMDes terhadap Pelaporan Aset Desa (Studi Fenomenologi Pada BUMDes Desa Karangbendo Kec Ponggok Kab Blitar). Prosiding Seminar Nasional Dan Call For Paper Ekonomi Dan Bisnis, 2017, 41-51.

Ittner, C. D., \& Larcker, D. F. (2003). Coming Up Short on Nonfinancial Performance Measurement Coming Up Short on Nonfinancial Performance Measurement The Idea in Brief The Idea in Practice. Harvard Business Review. www.hbr.org

Jaryono \& Tohir. (2019). Analisis Kinerja BUMDes "Mitra Usaha Makmur" Dalam Pengaruhnya Terhadap Pendapatan Asli Desa (PADes) Desa Susukan Kecamatan Sumbang Kabuoaten Banyumas. Sustainable Competitive Advantage (SCA), 9(23), 23-30. http://www.jp.feb.unsoed.ac.id/ind ex.php/sca-1/article/view/1390 Lumpkin n Dess. (n.d.).

Madjodjo, F., \& Dahlan, F. (2020). Analisis kinerja Badan Usaha Milik Desa dalam pengelolaan anggaran untuk meningkatkan pengolahan potensi desa di Desa Akedotilou. Indonesia Accounting Journal, 2(2), 187. https://doi.org/10.32400/iaj.31055

Munizu, M. (2010). Pengaruh FaktorFaktor Eksternal dan Internal Terhadap Kinerja Usaha Mikro dan Kecil (UMK) di Sulawesi Selatan. Jurnal Manajemen Dan Wirausaha, 12(1), 33-41. https://doi.org/10.9744/jmk.12.1.pp .33-41

Musyafak, F. (2014). Jurnal Penelitian Administrasi Publik | Vol 5 No. 2 Analisis Kinerja Badan Usaha Milik Desa (BUMDes) dalam Pengelolaan Aset Desa di Desa Putat Lor Kecamatan Menganti Kabupaten Gresik ( Studi Kasus di BUMDes Desa Putat Lor ). Jurnal Penelitian Administrasi Publik, 5(2), 1232-1237.

Okwoma, D. (2012). The Effect of Corporate Social Responsibility on the Financial Performance of Commercial Banks in Kenya. International Journal of Business and Public Management, 2(3), 3740.

Parijat, P. (2014). Motivationvroom. International Journal of Business and Management, VII(9), 1-8.

Peraturan Pemerintah 11 Tahun 2021 Tentang Badan Usaha Milik Desa. Peraturan Pemerintah 11 Tahun 2021 Tentang Badan Usaha Milik Desa, 0865, 1-71.

Pratiwi, M. B., \& Novianty, I. (2020). Strategi Bertahan Badan Usaha Milik Desa (BUMDes) dalam Pandemi COVID-19 pada Desa Cibodas Kecamatan Lembang Kabupaten Bandung Barat. Prosiding The 11th Industrial Research Workshop and National Seminar, 26-27.

Premananda, N. L. P. U. (2017). Pengaruh Akuntabilitas, Transparansi, Dan Partisipasi Anggaran Terhadap Kinerja Anggaran Pada Pemerintah Kota Denpasar. E-Jurnal Akuntansi, 18(3), 2451-2476. 
Qosjim, A. (2017). Analisis Kinerja BUMDes di Kabupaten Lumajang ( Performance Analysis BUMDes in Jember District). Journal Ekuilibrium, II(1), 10-17.

Rahmawati, E. (2020). Adaptasi Baru BUMDes di Era Pandemi.

Rosli, M. (2013). Entrepreneurial orientation and business performance of women-owned small and medium enterprises in Malaysia: Competitive advantage as a mediator. International Journal of Business and Social Science, $4(1), \quad 82-90$. https://doi.org/10.1177/026624261 2455034

Sadjiarto, A. (2000). Akuntabilitas Dan Pengukuran Kinerja Pemerintahan. Jurnal Akuntansi Dan Keuangan, 2(2), 138-150. https://doi.org/10.9744/jak.2.2.pp.1 38-150

Sinarwati, N. K., \& Prayudi, A. M. (2019). The Role of Village Own Enterprises to Rural Development. South East Asia Journal of Contemporary Business, Economics and Law. The Role of Village Own Enterprises to Rural Development. South East Asia Journal of Contemporary Business, Economics and Law, 18(5), 77-83. https://seajbel.com/wpcontent/uploads/2019/04/seajbel5VOL18_227.pdf

Sok P., \& Aron-O'Cass, S. K. M. (2013). Achieving superior SME performance: Overarching role of marketing, innovation, and learning capabilities. Australian Marketing Journal (AMJ), 21(3), 161-167.

https://www.sciencedirect.com/scie nce/article/

Sugiyono. (2010). Metode Penelitian Bisnis (Pendekatan Kuantitatif, Kualitatif dan $R \& D$ ).

Undang-Undang Republik Indonesia No. 6 Tahun 2014 Tentang Desa, 1 (2014).
Zehir, C., \& Can-Esin, K. T. (2015). Linking Entrepreneurial Orientation to Firm Performance: The Role of Differentiation Strategy and Innovation Performance. Procedia of Social and Behavioral Science, 358-367. Available online at www.sciencedirect.com 